3. Martin MH, Meadows J, McElhinney DB, Goldstein BH, Bergersen L, Qureshi AM, et al. Safety and feasibility of Melody transcatheter pulmonary valve replacement in the native right ventricular outflow tract. JACC Cardiovasc Intervent. 2018;11:1642-50.
4. McElhinney DB, Sondergaard L, Armstrong AK, Bergersen L, Padera RF, Balzer DT, et al. Endocarditis after transcatheter pulmonary valve replacement. J Am Coll Cardiol. 2018;72:2717-28.
See Article page 967.

\section{Commentary: Innovation in the clinical care of congenital heart defects: Surgeons can and need to weigh in}

David Kalfa, MD, PhD

Tannous and Nugent ${ }^{1}$ offer a very interesting perspective on interventionalists' current thinking and approach to transcatheter pulmonary valve replacement (PVR) for native right ventricle outflow tract (RVOT), the limitations of available devices, and what technologies could become available in the near term. They conclude that transcatheter PVR will become an option for most patients with native RVOT.

This is great news for patients. But there is still a world of uncertainties before transcatheter PVR becomes a safe, widely used, and sustainable option. The durability of transcatheter valves in a native/nonconduit RVOT is still unknown. Selection criteria and the influence of variable anatomy on device performance need to be investigated. The long-term outcomes of valve-in-valve procedures in this highly heterogeneous population remain to be shown.

Once these questions are answered, transcatheterdeployed bioprostheses will not be a panacea anyway. The valves currently being delivered still come with an

From the Section of Pediatric and Congenital Cardiac Surgery, Division of Cardiac, Thoracic and Vascular Surgery, New-York Presbyterian-Morgan Stanley Children's Hospital, Columbia University Medical Center, New York, NY.

Disclosures: The author reported no conflicts of interest.

The Journal policy requires editors and reviewers to disclose conflicts of interest and to decline handling or reviewing manuscripts for which they may have a conflict of interest. The editors and reviewers of this article have no conflicts of interest.

Received for publication Sept 11, 2020; revisions received Sept 11, 2020; accepted for publication Sept 14, 2020; available ahead of print Sept 18, 2020.

Address for reprints: David Kalfa, MD, PhD, Pediatric Cardiac Surgery, Columbia University College of Physicians and Surgeons, New York-Presbyterian Morgan Stanley Children's Hospital, 3959 Broadway, CHN-274, New York, NY 10032 (E-mail: dk2757@cumc.columbia.edu).

J Thorac Cardiovasc Surg 2021;162:972-3

$0022-5223 / \$ 36.00$

Copyright (c) 2020 by The American Association for Thoracic Surgery

https://doi.org/10.1016/j.jtcvs.2020.09.050
Check for updates

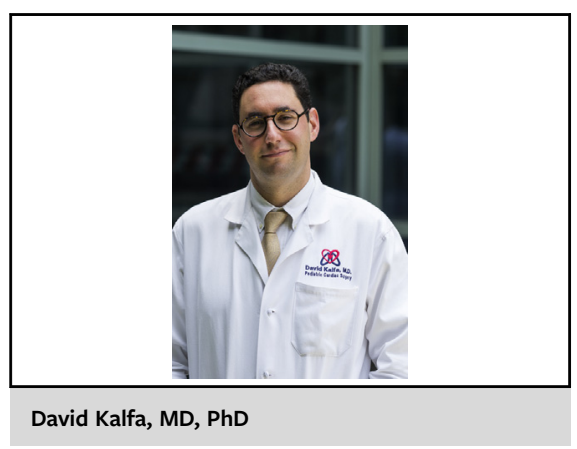

CENTRAL MESSAGE

Transcatheter technology offers

less-invasive options to patients

with native outflow tract but are

not a panacea. Surgeons need to

play an active role in innovation

to develop disruptive devices.

inevitable risk of structural degeneration. These patients have an excellent life expectancy and start the clock of repeat PVR quite early in life. Multiple valve-in-valve transcatheter PVR procedures carry a risk of vascular injury, tricuspid valve injury, and the intracardiac accumulation of large amounts of materials.

Despite these uncertainties and limitations, interventionalists deserve thunderous applause for making the field advance. But sustainable and durable valve replacement in the congenital (especially growing) population remain an unmet clinical need, and there is a lot of room for innovation. Surgeons can weigh in. Surgeons need to weigh in. And surgeons can play a significant role at multiple levels.

On the clinical side, the surgical community needs to keep pushing for sparing the valve at the initial surgery and repairing the valve at redo surgery. Surgeons need to play a proactive role on multidisciplinary teams that include interventionalists and imaging cardiologists to counsel and educate patients on the pros and cons of all options.

On the research side, surgeons (and surgeon-scientists) are ideally placed to develop both evolutionary and revolutionary innovative solutions. Developing a new antistructural 
degeneration process for animal-derived tissue would bring more benefit to patients than designing a new transcatheter device based on a regular porcine or pericardial bioprothesis. Surgeons can lead a collaboration with polymer scientists to develop a biostable and biocompatible polymeric material design to withstand the mechanical microenvironment of a cardiac valve. ${ }^{2}$ Developing an autologous and living valve by tissue engineering is a complex task but needs more brains to be accomplished. Expandable valves or valved conduits that can be implanted surgically in a neonate and expanded at the catheterization lab multiple times to accommodate the growth without implanting a new device each time are currently being developed by some surgeon-scientists. ${ }^{3,4}$

As Tannous and Nugent ${ }^{1}$ nicely show, transcatheter PVR will be a good solution for many patients with native RVOT. But let's not be blinded by transcatheter innovations that still expose patients to repeat procedures. Let's think disruptive. Let's think revolutionary. Let's think as surgeons.

\section{References}

1. Tannous P, Nugent A. Transcatheter pulmonary valve replacement in native an nonconduit right ventricle outflow tracts. J Thorac Cardiovasc Surg. 2021;162: 967-70.

2. Sun M, Giuglaris C, Li R, Ferrari G, Bacha E, Kysar J, et al. Development and characterization of an anisotropic biomimetic polymeric patch to improve the durability of surgical heart valve repair. Presented at: Heart Valve Society Annual Meeting; February 15-16, 2020; Abu Dhabi, United Arab Emirates.

3. Hofferberth SC, Saeed MY, Tomholt L, Fernandes MC, Payne CJ, Price K, et al. A geometrically adaptable heart valve replacement. Sci Transl Med. 2020;12: eaay4006.

4. Kalfa D, Li RL, Russ J, Pousse P-L, Paschalides C, Ferrari G. Materials, design, and manufacturing of a growth-accommodating pediatric heart valve prosthesis: from ideation to the first prototype. Presented at: American Association for Thoracic Surgery 100th Annual Meeting, April 25-28, 2020; New York, New York.
See Article page 967.

\section{Commentary: Transcatheter valve therapy for the right ventricular outflow tract: Right as rain, ready for Roger}

\author{
Sameh M. Said, MBBCh, MD, FACS
}

Transcatheter therapy revolutionized the care of pediatric and adult patients with congenital heart disease. More than 2 decades have passed since the introduction of transcatheter pulmonary valve (TPV) implantation by Bonhoeffer and colleagues, ${ }^{1}$ which resulted in significant paradigm shift in the way we think about the right

\footnotetext{
From the Division of Pediatric Cardiovascular Surgery, Masonic Children's Hospital, University of Minnesota, Minneapolis, Minn.

Disclosures: Dr Said is a consultant for Cryolife.

The Journal policy requires editors and reviewers to disclose conflicts of interest and to decline handling or reviewing manuscripts for which they may have a conflict of interest. The editors and reviewers of this article have no conflicts of interest.

Received for publication Sept 13, 2020; revisions received Sept 13, 2020; accepted for publication Sept 14, 2020; available ahead of print Sept 18, 2020.

Address for reprints: Sameh M. Said, MBBCh, MD, FACS, Division of Pediatric Cardiovascular Surgery, Department of Surgery, Masonic Children's Hospital, University of Minnesota, 2450 Riverside Ave S, East Building, MB 539, Minneapolis, MN 55454 (E-mail: ssaid@umn.edu).

J Thorac Cardiovasc Surg 2021;162:973-4

$0022-5223 / \$ 36.00$

Copyright (c) 2020 by The American Association for Thoracic Surgery

https://doi.org/10.1016/j.jtcvs.2020.09.047
}

\section{Check for updates}

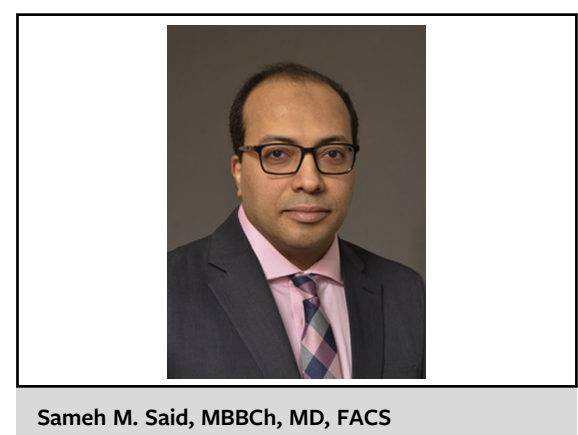

CENTRAL MESSAGE

Transcatheter pulmonary valve implantation in both native and nonconduit-related right ventricular outflow tract is a valid alternative to standard surgery. Long-term data are needed.

ventricular outflow tract (RVOT). Although the most common underlying indication for TPV is previous surgical repair of tetralogy of Fallot (ToF) with pulmonary stenosis, a fair number of patients have pulmonary atresia with primary transcatheter intervention to open the RVOT.

The indications for pulmonary valve replacement have been clear and the majority of these patients present with chronic free pulmonary regurgitation with evidence of right ventricular volume overload. Transcatheter 